JOURNAL OF SECURITY AND SUSTAINABILITY ISSUES

ISSN 2029-7017 print/ISSN 2029-7025 online

2021 Volume 11

https://doi.org/10.47459/jssi.2021.11.13

\title{
A COMPARATIVE ANALYSIS PERTAINING TO THE DESCRIPTION OF THE INSTITUTION OF A COMPLAINT LODGED BY DETAINEES IN SELECTED EUROPEAN COUNTRIES. DE LEGE LATA CONCLUSIONS AND DE LEGE FERENDA POSTULATES
}

\author{
Daniel Mielnik \\ Academy of Justice, 50 Wiśniowa Street, 02-520 Warsaw, Poland \\ E-mail:daniel.mielnik@swws.edu.pl
}

Received 15 November 2020; accepted 5 April 2021; published June 302021

\begin{abstract}
The aim of the comparative analysis presented here was in a way to show a catalogue of ways of handling cases in which the complainant is incarcerated. Additionally the aim of this study is an attempt at explicating the current legal status in Poland in terms of the institution of lodging complaints by detainees and its functioning, and to compile a comparative analysis in the same subject area. In addition, the aim of the study is an attempt to present de lege lata conclusions and de lege ferenda postulates in the context of the matter in question. It should be emphasized that the institution of a complaint is notoriously used by persons deprived of their liberty, which is clearly visible in the statistical analysis presented in the article. For this reason, it seems justified to undertake legislative work in cooperation with the Ministry of Justice and the Central Management of the Academy of Justice. This study uses a triangulation of the following research methods: descriptive research method, theoretical and legal method, comparative method with the elements of comparative law, and statistical method. The legal status adopted in the paper as on 30 October 2020.
\end{abstract}

Keywords: law; prisoner; security; complaint; petitions; de lege lata; de lege ferenda; comparative studies

Reference to this paper should be made as follows: Mielnik, D. 2021. A comparative analysis pertaining to the description of the institution of a complaint lodged by detainees in selected European countries. De lege lata conclusions and de lege ferenda postulates. Journal of Security and Sustainability Issues, 11, 169-178, https://doi.org/10.47459/jssi.2021.11.13

JEL Classifications: K10; K14; K23; K38; K42

Additional disciplines: law, security

\section{Introduction}

By way of introduction, it should be emphasized that the spiritus movens of this study is an expert opinion, which has been compiled in a comprehensive manner, prepared by the staff of the Research and Development Institute of the Academy of Justice, as commissioned by the Department for the Execution of Judgements and Probations of the Ministry of Justice (Nowak, Mielnik, Nowacki, Kasprzyk and Stachowicz, 2020) .

The expert opinion in question indicates that "the current scope, scale and ways of hearing the complaints lodged by the bodies of enforcement proceedings in Poland (i.e. penitentiary judges, administration of penitentiary units, Ministry of Justice) indicate the need to rationalize the legal provisions in this area" (B.M. Nowak et al., 2020, p. 5). In its subsequent parts, it was emphasised that the Ministry of Justice expresses an immediate need to compile mechanisms that limit the abuse of the right to lodge complaints by persons deprived of their liberty, which results in a significant involvement of human resources Penitentiary Service, as well as other bodies of this formation, in constructing a substantive response to allegations, demands and motions of detainees, which are constantly unjustified and irrelevant (B.M. Nowak et al., 2020). The analysis of this expert opinion also leads to the conclusion that the Ministry of Justice stresses that potential changes, or in concreto 
legislative interventions, should take into account the obligation to maintain high constitutional and international standards in relation to the rights of detainees (B.M. Nowak et al., 2020).

The aim of this study is an attempt at explicating the current legal status in Poland in terms of the institution of lodging complaints by detainees and its functioning, and to compile a comparative analysis in the same subject area. In addition, the aim of the study is an attempt to present de lege lata conclusions and de lege ferenda postulates in the context of the matter in question.

This study uses a triangulation of the following research methods: descriptive research method, theoretical and legal method, comparative method with the elements of comparative law, and statistical method.

The legal status adopted in the paper as on 30 October 2020.

\section{The analysis of the current legal status in Poland (de lege lata) concerning the institution of a complaint lodged by detainees}

The de lege lata analysis should commence with the regulations contained in the so-called Basic Law, as Article 63 of the Constitution of the Republic of Poland of 2 April 1997 (Journal of Laws of 1997, No. 78, item 483, as amended; hereinafter referred to as: "the Constitution of the Republic of Poland"), explicitly states that everyone shall have the right to submit petitions, proposals and complaints in the public interest, in his own interest or in the interests of another person - with his consent - to organs of public authority, as well as to organizations and social institutions in connection with the performance of their prescribed duties within the field of public administration. It should be stressed that the Constitution of the Republic of Poland offers a broad understanding of this law, anticipating that these may include petitions (i.e. applications, demands), motions (i.e. proposals), as well as complaints (Sokolewicz, Wojtyczek, 2016).

At the same time, it should be emphasised that the mere filing of a petition, motion or a complaint opens the proceedings, procedure of which is not in concreto regulated by the Constitution of the Republic of Poland. This is done, however, by the Act of 14 June 1960 - Code of Administrative Procedure (Journal of Laws of 2020, items 256, 695; hereinafter as: 'CAP'), which explicitly states that the right, guaranteed in the Constitution of the Republic of Poland, of every citizen to submit petitions, complaints and motions to state bodies, local government bodies, self-government organizational units and social organizations and institutions - is implemented in accordance with the principles set out in the above Act (see Section VIII of c.a.p., entitled 'Complaints and Motions'). Importantly, CAP - parallel to the content of Article 63 of the Polish Constitution - also states that petitions, complaints, and applications may be submitted, in the public interest, in his own interest or in the interests of another person - with his consent - to organizations and social institutions in connection with the performance of their prescribed duties within the field of public administration (Article 221 of CAP; more on the subject: Jaśkowska, 2019).

In turn, in the context of the lex specialis provisions contained in the Act of 6 June 1997 - The Executive Penal Code (Journal of Laws of 2020, items 523, 568; hereinafter as: the 'EPC', which provide, inter alia, that a convicted person retains civil rights and freedoms, and their limitation may result only from the Act and a judgement passed on its basis (Article 4 of the EPC). Such a formulation, as emphasized by Nowak et al. (2020), thus establishes the legal position of the convicted person (importantly, this notion should also be understood as a person remanded in custody under Article $242 \S 1$ of the EPC) with regard to the right to lodge complaints under the applicable legal order, on a par with other citizens of the state. Moreover, B.M. Nowak et al. (2020) demonstrated that "(...) applying the so-called principle of subjectivity within the scope of the rights and obligations specified in the code (Article $5 \S 1$ of the EPC), in the catalogue of statutory powers, the convicted person in concreto was granted the right to lodge complaints to the authority competent to hear them and to present them to the administrative authorities of the prison, heads of organisational units of Penitentiary Service, a penitentiary judge, a prosecutor and the Ombudsman (Article 102 (10) of the EPC)". (B.M. Nowak et al., 2020, p. 10). 
It should be emphasized that the Executive Penal Code includes the so-called delegation of legislative powers to the Minister of Justice to issue a regulation on the manner of handling motions, complaints and requests of persons detained in penitentiary institutions and custody suites, as well as the rules and procedures for receiving and recognizing motions, complaints and requests, and for recording and documenting them (Article 249 $\S 3$ (3) of the EPC).

A person deprived of liberty may submit motions, complaints and requests to all entities indicated in Article 2 of the EPC, which lists a catalogue of the bodies of enforcement proceedings, i.e.:

- the court of first instance or another equivalent court;

- the penitentiary court;

- the court referendary;

- the president of the court or an authorised judge;

- the penitentiary judge;

- the director of the penitentiary institution, custody suite, as well as the district director and the General Director of Penitentiary Service, or the person in charge of another facility provided for in the provisions of the executory criminal law, and the penitentiary committee;

- the court-appointed probation officer and the head of the probation service team;

- court or administrative enforcement authority;

- head of the tax office;

- relevant local government administration authority or self-government body;

- other body empowered by law to enforce judgements.

According to M. Płatek, convicted persons, including those who are deprived of their liberty, retain the right to make collective written submissions in the form of a petition (Płatek, 2000). A detained person also has the right to lodge a constitutional complaint with the Constitutional Tribunal (Article 79 of the Constitution of the Republic of Poland), submit motions to the Ombudsman (Article 9 (1) of the Ombudsman Act of 15 July 1987, Journal of Laws of 2020, item. 627), and to lodge complaints under international law (United Nations Standard Minimum Rules for the Treatment of Prisoners [the so-called Nelson Mandela Rules] and European Prison Rules).

It is also worth restating the individual implementing acts (i.e. regulations), which are related in concreto to the subject matter of this study. These are:

- $\$ 21$ and 22 of the ordinance of the Minister of Justice of 21 December 2016 on the regulations governing the organization and orderly execution of imprisonment (Journal of Laws No. 2231);

- $\S 22$ and 23 of the ordinance of the Minister of Justice of 22 December 2016 on the regulations governing the organisational and orderly execution of temporary custody (Journal of Laws, item 2290);

- the provisions of the ordinance of the Minister of Justice of 13 August 2003 on the methods of settling motions, complaints and requests of persons detained in prisons and custody suites (Journal of Laws of 2013, item 647).

In accordance with the norms contained in the latter act - complaints related to the activities of organisational units, and the conduct of officers and employees of Penitentiary Service shall be considered by:

- the head of an organisational unit, if the complaint is addressed to him, and does not concern his direct activity or the direct activity of his deputy and the decisions taken by them, unless it is considered legitimate in this respect ( $\$ 3$ (1) (1) of the regulation in question);

- the field director of Penitentiary Service, if the complaint is related to the activity of the organisational unit he supervises and has not been previously handled by a designated head of an organisational unit (§ 3 (1) (2) of the regulation in question

- the General Director of Penitentiary Service, or a person appointed by him, if the complaint is related to the activity of a district inspectorate of Penitentiary Service and has not been previously settled by a designated head of an organisational unit (§ (3) (1) (3) of the regulation in question); 
- the Minister of Justice or a person appointed by him, if the complaint is related to the activity of the Central Board of Penitentiary Service and has not been previously settled by a designated head of an organisational unit (§ 3 (1) (4) of the regulation in question).

As emphasised by B.M. Nowak et al. (2020), the authority competent to handle a motion, complaint or request shall be obliged to notify the applicant in writing of the manner in which the case has been handled, except, however, for requests and motions made personally by a person detained in prison or custody suite in their own case, as well as those handled immediately after their submission. If the director of a prison or custody suite has not acceded to the complaint, he or she shall instruct the complainant of his or her right to lodge a complaint to the competent authority, i.e. the field director of Penitentiary Service, related to the manner in which it has been handled.

In order to illustrate the extent to which the institution of a complaint lodged by detainees has been used, the author of this study has prepared a statistical analysis of the number of complaints lodged over the period 2014-2018 (see: Figure 1).

Figure 1. Statistical analysis of the complaints lodged by detainees between 2014 and 2018

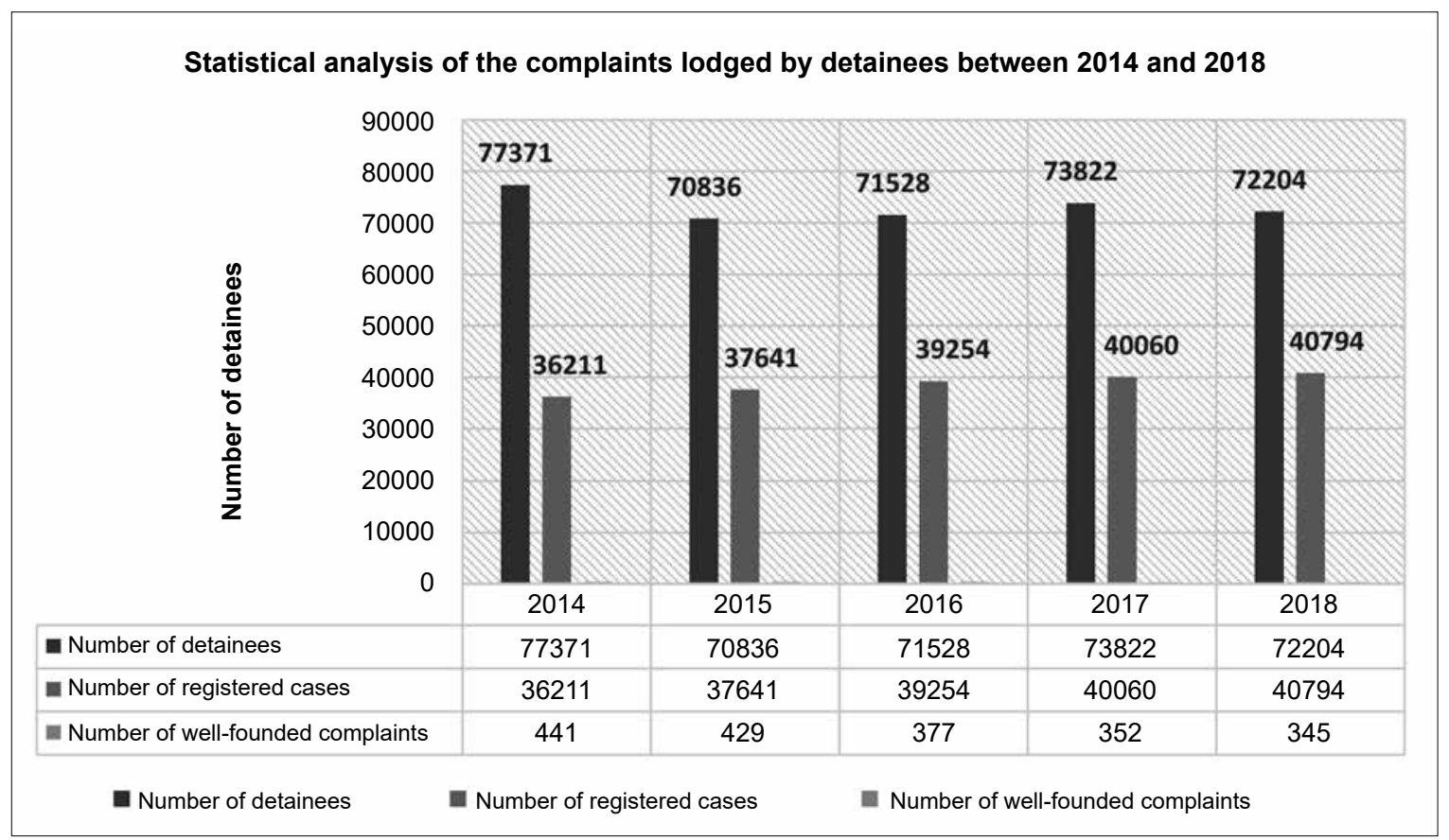

Source: Nowak et al., 2020; Office of the Internal Affairs of the Central Management of Penitentiary Service $(2014,2015,2016,2017,2018)$

As can be seen, the number of registered complaint cases is (slightly) increasing from year to year. This trend has been perfectly described by B.M. Nowak et al. (2020) in his expert opinion, as it shows that the institution of complaints is permanently abused by detainees, and has become a symbol of fighting against the system and the penitentiary, as shown in concreto by the number of legitimate cases in relation to the total number of registered cases.

\section{A comparative analysis of the institution of complaints lodged by detainees in selected European countries}

This part of the study is a synthetic comparative overview of the institution of complaints lodged by detainees in selected European countries. The author has adopted the following methodology - first, of course, a given country is mentioned, then the legal basis for the complaint in concreto is indicated, followed by a broader comment. 


\section{a) Germany}

Legal basis:

1976 Act on the Execution of Prison Sentences and Measures of Reform and Prevention Involving Deprivation of Liberty (so-called Prison Act)

Gesetz über den Vollzug der Freiheitsstrafe und der freiheitsentziehenden Maßregeln der Besserung und Sicherung (Strafvollzugsgesetz - StVollzG)

Pursuant to $\S 108$ of the above-mentioned Act - a prisoner has the possibility to address the head of the institution with motions and complaints in matters that concern him/her. In order to enable the exercise of this right for the detainees - regular hours of admission are set.

\section{b) France:}

Legal basis:

Code of criminal procedure of 1959

Code de procedure penale

Under Article D.259 of the above-mentioned act, any prisoner may present their requests or complaints to the prison director. Any prisoner may ask to be heard by court officers, as well as by the officials visiting or inspecting the establishment, without the presence of the staff of the facility in which he or she is serving the sentence.

\section{c) Spain}

Legal basis:

General Penitentiary Organic Act of 1979.

Ley Orgánica 1/1979, de 26 de septiembre, General Penitenciaria

Pursuant to Article 50 of the Act in question, persons deprived of their liberty have the right to submit petitions and complaints. They should be related to how the prisoners are dealt with or violating prison regulations. The said petitions or complaints shall be submitted to the director or the person who represents him, in order to take appropriate steps or possibly to pass them on to the competent authorities or bodies. Importantly, if the complaint or petition has been made in writing, it may be submitted in a closed envelope against a receipt of this action.

\section{d) Lithuania}

\section{Legal basis:}

Lithuanian Penitentiary Code (Latvijas Sodu izpildes kodekss);

Act on the Deprivation of Liberty Procedures (Apcietinājumā turēšanas kārtības likums)

Under the above-mentioned Code, prisoners have the right to submit suggestions, motions, petitions and complaints to officials of national and municipal institutions, public organisations and international institutions. Complaints shall be dealt with within 20 working days of their receipt. In turn, the replies to the motions and complaints of the detainees should be provided to them within two working days of signing the official reply. Replies from international institutions should be provided even sooner, one working day after their receipt. It is worth pointing out that persons deprived of their liberty must not send anonymous or collective complaints to officials of national and municipal institutions, or file motions and complaints on behalf of another convicted prisoner or with the exclusion of the intermediary of prison administration. Another Lithuanian solution in the context of complaints lodged by detainees deserves particular attention, namely that the expenses related to sending requests and complaints are covered by the detainees themselves. As a consequence, where a prisoner wishes to attach copies of documents or other materials to his motion or complaint, the prison administration shall charge a fixed fee from the detainees personal account upon providing him or her with a copy.

\section{e) Latvia}

Legal basis:

The Sentence Execution Code of Latvia

Pursuant to Article 50 of the above Code, persons deprived of their liberty have the right to write complaints to public authorities, public organisations and officials. Complaints by detainees concerning matters related to the 
circumstances of sentence execution shall be examined by directors of penitentiary units. It is worth pointing out that letters from convicted persons addressed to state and local institutions, the Office of the Ombudsman, the United Nations, the Council of Europe, the Committee on Human Rights and Public Affairs of the European Parliament, the public prosecutor's office, courts, lawyers - are not subject to examination by the penitentiary unit (i.e. they are outside the jurisdiction of the unit). With regard to these Lithuanian solutions, the costs related to sending complaints to non-penitentiary institutions in Latvia are covered by the special budget for persons deprived of their liberty where there are no adequate funds in the detainees' personal account. In addition, detainees have the right to make an oral complaint. Interestingly, a detainee can be heard with no presence of third parties at his or her express wish.

\section{f) The Czech Republic}

\section{Legal basis:}

Act No 169/1999 Coll. on serving a sentence of imprisonment; Act on Execution of a Sentence of Imprisonment The Imprisonment Act For purposes of the Prison Service of the Czech Republic; Decree of the Ministry of Justice No 345/1999 Coll. on the procedure of serving a sentence of imprisonment; Decree of the Director General No 55/2014 on the handling of prisoners' complaints and motions.

The regulations governing complaints and motions are set out in several documents:

- Act 169/1999 Coll. on serving a sentence of imprisonment; Decree of the Ministry of Justice No. 345/1999 Coll. on the procedure of serving a sentence of imprisonment; Decree of the Director General No. 55/2014 on the handling of prisoners' complaints and motions.

At the beginning it should be emphasised that the management of Penitentiary Service, as a rule, has a 30-day period to respond to a prisoner's motion or complaint. In serious cases where the content of the letter justifies it, this limit may be extended up to 60 days. The above-mentioned Act No 169/1999, concerns general issues connected with serving the term of imprisonment, including the prisoners' right to make complaints. A Decree of the Ministry of Justice, in turn, also lists the international institutions to which prisoners may submit complaints. The decree in question specifies in detail what is and what is not a complaint. Interestingly, special quasi-boxes for complaints are placed in the prison corridors, which does not exclude situations where they are passed on directly to the officers or to the corrections unit supervisor. Complaints about improper behaviour by staff or violations of the law are handled by the Prevention and Complaints Unit in prisons, or by the Prevention and Control Department (i.e. headquarters). It is worth pointing out that the director of the prison, in a way, appoints (designates) a group of Penitentiary Service employees who are responsible for collecting and sending complaints and motions, as well as recording them. Penitentiary Service staff are also obliged to inform the director of the prison, the public prosecutor, the judge or the body that is responsible for prison supervision that the prisoner has requested to speak with them and allow them to speak in prison, if approved by that person.

\section{g) Slovakia}

\section{Legal basis:}

Act No. 4/2001 Coll. on the Prison Service and Court Guard Corps; Regulation of the Minister of Justice of the Slovak Republic No 14/2015 regulating the procedure of handling complaints in the Prison Service and Court Guard Corps; Act on the Execution of Imprisonment Sentence; Act on Free Access to Information

Pursuant to Act No. 4/2001 Coll. on the Prison Service and Court Guard Corps, the corps in question handles complaints from detainees and prisoners. An important change in the manner of receiving, registering, investigating and processing complaints from persons deprived of their liberty was the amendment of this Act, carried out in 2016. It was aimed in particular at the following:

- removing the multi-stage procedure in the same case (this applies only to the situation of submitting a complaint about the way in which it is examined; importantly, there is only one possibility of filing a motion for the examination of a complaint);

- shortening the period within which a complainant is entitled to lodge a complaint about an infringement of his right (from five years to six months from the moment of the infringement); this change in question is aimed at 
increasing the effectiveness of verification with regard to the allegations;

- establishing the jurisdiction of the prison to hear complaints against which a complaint has been made, so that the unit can react immediately to possible violations of detainees' or prisoners' rights and ensure that such unwanted actions are immediately eliminated. It is worth pointing out that in a situation when a complaint ihas been made against the management or head of a special unit of the Corps, General Directorate of the Corps is competent to consider such a complaint. In addition, the Slovak Law on the Corps also specifies situations where the Ministry of Justice is competent to consider a complaint lodged by a detained person. In order to ensure a uniform procedure for handling complaints within the Corps, Regulation No 14/2015 of the Minister of Justice of the Slovak Republic was issued, regulating the procedure for handling complaints within Prison Service and Court Guard Corps. In particular, it regulates the procedures for receiving complaints from persons deprived of their liberty, including their registration, assessment of their content and handling and possible investigations. In order to eliminate possible conflicts of interest, while respecting the principles of objectivity and impartiality in the handling of complaints, it shall not be assigned to the person against whom it is directed, including against an employee in his managerial capacity. In order to guarantee the rights of prisoners in accordance with the Law on execution of imprisonment sentences, they have the right to submit applications to the state bodies of the Slovak Republic which are competent to handle motions concerning the protection of human rights, as well as to treaty-based international bodies and international organisations. The penitentiary unit is obliged to send them immediately, while maintaining the anonymity of the sender. The detainee also has the right to hold interviews with the management of the unit or with an officer appointed by the management of the prison and with the persons and representatives of the following authorities at the time of supervision in the prison:

- the public prosecutor supervising the observance of the rule of law in the prison;

- representatives of the National Council of the Slovak Republic;

- the Minister of Justice and persons appointed by him;

- legal persons or natural persons if it is provided by special regulations or an international convention by which the Slovak Republic is bound.

\section{h) Croatia}

\section{Legal basis:}

\section{Act on Execution of a Sentence of Imprisonment}

On the basis of the above-mentioned normative act, a prisoner has the right to lodge a complaint against the proceedings, as well as against the decision of an employee of the penitentiary unit. Importantly, a person deprived of liberty may file it, either orally or in writing, to the head of the penitentiary unit (the so-called unit manager) or to the Central Office of the Prison System Directorate operating at the Ministry of Justice (the equivalent of the Polish Central Management of the Penitentiary Service). It is important to stress that the complaint made in writing to the Prison System Directorate is delivered in a package that cannot be opened by the administration of the prison unit in which it was filed. Another solution, based on the Croatian legal system, is that a prisoner has the right to lodge a written complaint in a closed envelope also with the court and the penitentiary judge. Furthermore, as indicated above, a prisoner is allowed to make an oral complaint without the presence of an employee of the penitentiary unit or the person against whom the complaint is made. The director (i.e. the manager) of the penitentiary unit is obliged to respond to the filed complaint within 15 days, and the Prison System Directorate - within 30 days. If a detainee makes a written complaint to the court, the response time is also 30 days. Interestingly, a detainee may lodge a complaint with the court against the decision of the head of the penitentiary unit within eight days of receiving it (unless the law states otherwise). When it comes to the question of administrative handling of the complaint, it is worth pointing out that written complaints are responded to in the same way.

\section{i) Malta}

Legal basis:

Subsidiary Legislation 260.03 Prisons Regulations

All complaints lodged by a detainee and requests to meet with the director, management, or member of the 
prison unit shall be recorded by a member of the Penitentiary Service. The officer shall then immediately forward the complaint to the Director of the unit. The Director, on the other hand, is obliged to meet the prisoner who made the request without undue delay. It should be pointed out, however, that where a detainee requests a visit from a member of the management, the Director must take steps so that the Secretary of that management is informed of the request within a reasonable time. It is particularly noteworthy that officers in such a formation who come into direct contact with prisoners shall, at their request, provide them with an appropriate form approved by the Director of the unit concerned for the purpose of submitting a formal motion, complaint or petition. As shown in other legislation, detainees under Maltese law may lodge complaints in any form.

\section{j) Sweden}

Legal basis:

KVFS 2011:2 - Kriminalvårdens föreskrifter och allmänna råd om häkte

The rules of Penitentiary Service procedure and general instructions on deprivation of liberty

On the basis of the above-mentioned act, prisoners'complaints may be filed individually and, in specific cases, by a quasi-council (the detainees' commission). Importantly, they have the right to lodge a written complaint at any time to both the local authorities and public administration authorities at the headquarters of the penitentiary unit. Complaints lodged in writing are subject to registration in a special system. A reply to a complaint can be made in writing or orally (in accordance with the procedural requirements under the Administrative Procedure Act). As regards the rules and general instructions of the Swedish Prison and Probation Service, they also state that if a detainee wishes to speak to a representative of the senior management of the penitentiary unit, he or she is entitled to do so, but the meeting itself is organised at a time suitable to the management (KVFS 2011:2).

\section{k) Romania}

\section{Legal basis:}

Criminal Code, the Code of Criminal Procedure, Law no. 254/2013 regarding the execution of the punishments and of the deprivation of liberty measures ordered by the judicial bodies during the criminal trial Regulation of March 10, 2016; LEGE no. 254 din 19 iulie 2013; Law no. 275/2006, the legislative framework in the field of the execution of punishments; Law no. 27/2002 regarding the regulation of the activity of solving the petitions

Romanian legislation guarantees the right of a detainee to file a petition and to exchange broadly defined correspondence. The term 'petition' should be understood as any request or complaint addressed to public authorities, public institutions and judicial bodies, national and international courts. In order to prevent the introduction of drugs, toxic substances, explosives or other prohibited objects to penitentiary units by means of such correspondence, envelopes shall be opened in the presence of the detainee but without reading the contents of the letter. According to Romanian legislation, each detainee is entitled to submit these petitions to the management of the prison, the judge supervising the deprivation of liberty (operating within the prison), courts, human rights NGOs, the National Preventive Mechanism within the institution of the Ombudsman, as well as to other public authorities and institutions. In addition, detainees shall have the right to address the institutions they deem appropriate with regard to any aspect concerning the way in which an imprisonment sentence is executed. It is worth stressing that those to whom complaints (i.e. petitions) are addressed are obliged, within 30 days from the date of registering the petition, to inform the petitioner whether the solution is favourable or unfavourable. In a situation where the substantive issue of a petition is extensive and requires detailed information and research, the head of a public authority or institution may extend the deadline for providing a reply by a maximum of 15 days.

\section{De lege lata conclusions and de lege ferenda postulates}

In relation to the above, it should be stressed that it would be an excellent solution for the Polish legal system to develop and implement a special official form with the use of which detainees could lodge complaints. This solution will, in a way, force detainees to use a synthetic form. It is important to note that such a procedure will allow the substantive unit to handle such cases reliably and efficiently. 
An even better solution would be to develop an electronic system similar to that used in government and local government administration units, i.e. Electronic Documentation Management. In this way, prison administration would be freed from piles of complaints lodged in writing. In such a system detainees would file electronic complaints (e-complaints) on devices indicated by the administration of a given penitentiary unit - obviously under the supervision of an officer. Once lodged, the system will automatically generate a unique code which can be used by the detainee to monitor the process and the way the case is handled in the system.

Another solution that could be used in Polish penitentiary units is to create a system that will provide a basis for the efficient issuing of solutions to similar problems of detainees. It is important to note that a quasi-base of solutions to the cases could contribute to the development of a uniform methodology of procedure (something like the maintenance of a uniform ruling practice by the Supreme Court).

It should also be considered that the introduction of rigour in terms of increasing formalism in the process of filing complaints will de facto combat groundless complaints.

In turn, in the process of handling a complaint lodged by a detainee, it should be examined ex officio at the very beginning whether the complaint has the status of a complaint, de facto and de jure.

In line with solutions in other countries, a new complaints procedure should be proposed, which at the same time ensures the protection of human rights (the rights of the detainee) while maintaining high constitutional and international standards, and at the same time respecting the economy of proceedings.

It is worth noting that a complaint, as a tool to protect the interests of the detainee, must not be abused, as the consequence of such abuses may lead to a depreciation of its importance (B.M. Nowak et al., 2020; Snopek, 2013, 2018, 2019).

In addition, a quasi-monitoring of the correct application of Article $6 \S 2$ and 3 of the EPC should be introduced in terms of the possibility of leaving complaints without consideration, as well as the provision of increased educational and psychological care to those detainees who present personality disorders that are manifested in their attitude of demand and the tendency to have negative attitudes towards actions taken by the Penitentiary Service. (B.M. Nowak et. al., 2020).

\section{Conclusions}

To summarise the above considerations, it should be pointed out that there is currently no legislative deficit in the subject matter of this study. This does not mean, however, that specific interventions aimed at improving the system should not be undertaken. The aim of the comparative analysis presented here was in a way to show a catalogue of ways of handling cases in which the complainant is incarcerated.

At this point it should be stressed again that the institution of a complaint is notoriously used by persons deprived of their liberty, as is clearly shown by the statistical analysis presented in the paper. For this reason, it seems justified to undertake legislative work in cooperation with the Ministry of Justice and the Central Management of the Academy of Justice.

\section{References}

Office of the Internal Affairs of the Central Management of Penitentiary Service (2014, 2015, 2016, 2017, 2018). Downloaded from: https://www.sw.gov.pl/dzial/statystyka (30 June 2020)

Jaśkowska, M. (2019). Updated commentary to Article 221 of the Administrative Procedure Code. In: M. Jaśkowska, M. WilbrandtGotowicz, A. Wróbel. Updated commentary to the Administrative Procedure Code. Warsaw: LEX/el.

Nowak, B.M., Mielnik, D., Nowacki, Z., Kasprzyk, M., Stachowicz, A. (2020). Comparative and legal research on the procedures, mode, manner and scope of handling complaints and the bodies authorised to handle complaints from persons serving sentences, and measures resulting in imprisonment in selected European countries. Higher School of Criminology and Penitentiary Sciences in Warsaw and the Institute of Justice. Downloaded from: https://iws.gov.pl/analizy-i-raporty/ekspertyzy/ (30 June 2020) 
Płatek, M. (2000), Role of executive penal law in crime prevention. Studia Iuridica, no. 38, pp. 109-132.

Snopek, M. (2013). Man in penitentiary isolation - negative consequences and forms of adaptation. In: M. Snopek, I. Mudrecka (ed.). Institutional Rehabilitation - barriers and opportunities. Opole.

Snopek, M. (2018). Making complaints by the detainees as the new form of 'fighting the system'. „Acta Elbingensia” vol. 39, No. 4, Elbląg.

Snopek, M. (2019). The sense and the lack thereof in convicts' claims - legal and pedagogical aspects of the institution of a complaint in the reality of Polish prisons. In: A. Kotlenga, M.H. Kowalczyk, Mackojć D. (ed.). New perspectives for the development of social rehabilitation education, Toruń.

Sokolewicz, W., Wojtyczek, K. (2016). Comments to the Article 63 of the Polish Constitution. In: L. Garlicki (ed.). M. Zubik (ed.), W. Sokolewicz [et al.]. The Constitution of the Republic of Poland. Commentary. Volume II, Warsaw: LEX/el.

The Act of 14 June 1960 - Administrative Procedure Code (Journal of Laws of 2020, item 256, 695)

The Ombudsman Act of 15 July 1987 (Journal of Laws of 2020, item 627)

The Constitution of the Republic of Poland 2 April 1997 (Journal of Laws from 1997, no 78, item. 483, as amended)

The Act of 6 June 1997 - The Executive Penal Code (Journal of Laws of 2020, item 523, 568)

The ordinance of the Minister of Justice of 13 August 2003 on the methods of settling motions, complaints and requests of persons detained in prisons and custody suites (Journal of Laws of 2013, item 647)

The ordinance of the Minister of Justice of 21 December 2016 on the regulations governing the organization and orderly execution of imprisonment (Journal of Laws item 2231)

The ordinance of the Minister of Justice of 22 December 2016 on the regulations governing the organisational and orderly execution of temporary custody (Journal of Laws, item 2290)

Daniel MIELNIK born on February 11, 1993, master of law, assistant at the Research and Development Institute of the Academy of Justice, expert in the Criminal Law Department of the Legislative Department of Criminal Law in the Ministry of Justice, graduate of the Law Leaders Studio, scholar of the Lubomirski Foundation, member of the ministerial competition jury (appointed by the Minister of Justice on the basis of order No. 287/18 / DPA of the Minister of Justice of September 18, 2018 for the study "Animal Protection Act legal information booklet for practitioners"), author of the monograph entitled "The death penalty in Polish criminal law. Historical and dogmatic reflections" (2017) and dozens of publications.

ORCID ID: https://orcid.org/0000-0001-6508-0273 